\title{
In-Vitro Antimicrobial Activity of Herbal Extracts From Tabuk Region (Kingdom of Saudi Arabia) Against Nosocomial Pathogens: A Preliminary Study
}

\author{
Farheen Fatima ${ }^{1}$, Showket Hussain Bhat ${ }^{1}$, Mohammad Fahad Ullah ${ }^{1}$, Faisel Abu-Duhier ${ }^{1} \&$ Eram Husain $^{1}$ \\ ${ }^{1}$ Department of Medical Laboratory Technology, Faculty of Applied Medical Sciences, University of Tabuk, \\ Tabuk, KSA \\ Correspondence: Farheen Fatima, Department of Medical Laboratory Technology, Faculty of Applied Medical \\ Sciences, University of Tabuk, Tabuk 71491, KSA. Tel: 96-653-807-4940. E-mail: f.khizar@ut.edu.sa
}

Received: January 3, 2018 Accepted: February 7, 2018 Online Published: February 9, 2018

doi:10.5539/gjhs.v10n3p83 URL: https://doi.org/10.5539/gjhs.v10n3p83

\begin{abstract}
Aim: The study aims to investigate the antimicrobial activity of herbal extracts from Tabuk region against nosocomial pathogens.

Material and Methods: The plants included in this study were collected according to United States Department of Agriculture (USDA). The plants were grinded into fine powder using electric grinder, and the powder was transferred into air tight containers. Extracts of this powder was prepared in form of stock solution that was further used for preparing solutions of different concentrations. Antibacterial tests including minimum inhibitory concentration and maximum bactericidal concentration, broth dilution method, and well-diffusion method were performed.

Results: The current study has determined the herbs that possess antimicrobial activity against the most common nosocomial pathogens. The sample extracts including Achinella fragrantissima, Artemisia judaica, Caralluma quadrangular, Cleome droserifera, Rhyza stricta, Moringa, and Ochradenus baccatus were tested for organisms including; Escherichia coli, Pseudomonas aeruginosa, Staphylococcus aureus, and Candida albicans. The results have depicted positive anti-microbial activity of herbal shrubs.
\end{abstract}

Conclusion: The results have demonstrated positive and promising anti-microbial activities against the nosocomial pathogens.

Keywords: anti-bacterial tests, anti-microbial activity, bacteria, fungi, herbal extracts, nosocomial pathogens

\section{Introduction}

The occurrence of infections can be widely viewed through myriad fungi or bacteria, which becomes a cause of severe illness. In Saudi Arabia; the studies related to nosocomial infections are limited. Studies have reported around 48\% nosocomial infections among the Saudi patients (Abdel-Fattah, 2005; Sabra \& Abdel-Fattah, 2012). The most important bacteria and fungi causing systemic infections reported by CDC included Escherishia coli, Klebsiella Sps, Pseudomonas aeruginosa, Salmonella Sps., Staphylococcus aureus, and Candida in United States (Centres for Disease Control and Prevention, 2013). The nosocomial infections include fungal and bacterial infections, and are aggravated by the reduced antibiotic susceptibility of the microbe. The acceleration of drug resident pathogens is emerged increasingly, leading to challenge the efficacy of essential antimicrobial treatment. Thereby, the development and replacement of new drugs are outpaced through the speed with which these drugs are lost. Certainly, the implications of these pathogens surpassed a renaissance of severe infections, threatening number of life-prolonging and life-saving interventions, including organ transplantations, cancer treatments, and sophisticated surgical operations. According to Scott (2009), the hospitals have instigated hotbeds to control the accelerating extent of severe infections and to restructure the existing procedures.

World Health Organization (WHO) has taken a positive step to combat drug resistance by setting out measures for governments and their national partners. The development of new tools and foster innovation are important measures in the policy of WHO. The instigation of these schemes was appropriate to encourage the drug industry for developing new antimicrobial drugs for future illnesses. Conversely, pharmaceutical companies have 
immensely used herbal medicine for drug preparation. Herbalism is a traditional practice of medicine, which is relied on the plants' usage and their extracts. There are a number of herbal medicines used by physicians; such as quinine, opium, digitalis and aspirin. In its report, WHO has reported that physicians in United States are using 25\% of modern drugs extracted from plants (Llewellyn et al., 2010). Plant extracts are the most promising source of such compounds and Arab world has been known for its medicinal herbs.

Tabuk province has rich habitats for plant growth owing to favorable climate of the North western region of Saudi Arabia. The database search on world-wide-web showed Tabuk region of Saudi Arabia to be rich in diverse flora (Llewellyn et al., 2010). Its floral diversity extends over a number of regions including; the Jabal Lauz of Hijaz Mountains, the Great Nafud and Ar'ar regions, Deesa, and Harrat-ar-Raha nature reserve, which are distributed as wadis, hills, and plains. According to Llewellyn et al. (2010), pharmaceutical companies have launched an important plant area (IPA) in the Arabian Peninsula. The vegetation of Tabuk region is mainly composed of chinopods along with other xerophytic vegetation. Significant literature is available for the plants, which possess potential medicinal benefits.

\section{Materials and Methods}

\subsection{Plant Identification and Collection}

The plants were collected according to the guidelines of United States Department of Agriculture (USDA). The samples of collected plants were submitted to the department of Biology (Botany), Faculty of Science, University of Tabuk, for their identification. Table 1 has discussed 7 plants that are selected and perceived in the current study.

Table 1. Details about seven selected plants

\begin{tabular}{lll}
\hline Plant name & Effect/ traditional use & Reference \\
\hline Cleome droserifera & For treatment of wounds. & 7 \\
Rhazya stricta & Antimicrobial against ESBL producing pathogens. & 8 \\
Ochradenus baccatus & Antimicrobial action studied limits only to fish pathogens. & 10 \\
Artemisia judaica & Antihelmenthic action stated, but antimicrobial remains 11 \\
unexplored. & & 13 \\
Achillea fragrantissima & Used as traditional anti-helmenthic medicine. Antimicrobial & \\
Caralluma quadrangula & action unexplored. & 14 \\
Invitro cytotoxic action studied, antimicrobial activity & 14 \\
Moringa leaves & unexplored. & - \\
\hline
\end{tabular}

\subsection{Preparation of Extracts}

The dirt and unwanted substances were removed from the collected plants by washing them gently with distilled water. The plants were dried in shade at room temperature. Care was taken to retain the activity of heat labile components of the plants during drying. The air-dried plants were crushed in the mortar and pestle. Electric grinder was used for further grinding of plants into fine powder. The obtained powder was transferred to air-tight containers, labelled, and stored in the laboratory away from sunlight.

The plant extracts were prepared by following the method described by Pinelo et al. (2009) with few modifications. The sample powder weighed 250-300 $\mathrm{g}$ and was soaked in 2 liters of $80 \%$ methanol in a conical flask. The conical flasks were placed in the water bath at $40^{\circ} \mathrm{C}$ for 24 hours with constant shaking. The extract mixture was strained using double layer cheese cloth. The obtained filtrate was further filtered using double layered Whitman filter paper. The filtrate was concentrated under reduced pressure at $35{ }^{\circ} \mathrm{C}$ using the Bucchi system. Further, the concentrated extracts were subjected to vacuum at $-30^{\circ} \mathrm{C}$ for 3 to 4 days to yield a solid or thick paste like product, which was refrigerated until used. The paste was dissolved in DMSO to prepare the stock solution of $1000 \mathrm{mg} / \mathrm{ml}$ concentration. The stock solution was used to prepare the different concentration solutions $(500 \mathrm{mg} / \mathrm{ml}, 250 \mathrm{mg} / \mathrm{ml}$, $125 \mathrm{mg} / \mathrm{ml}$ ) for antimicrobial assays.

\subsection{Antimicrobial Assays}

Crude methanol extracts of the collected herbs were used as test material. American Type Culture Collection 
(ATCC) strains of Escherichia coli, Pseudomonas aeroginosa, Staphylococcus aureus and Candida albicans were used. All microbial work was conducted in accordance with guidelines of the NCCLS.

\subsection{Antibacterial Tests}

2.4.1 Minimum Inhibitory Concentration and Maximum Bactericidal Concentration

Minimum inhibitory concentration (MIC) of each herbal extract was determined with strains grown in cation adjusted Muellor-Hinton broth by Macrobroth dilution method according to NCCLS guidelines. The crude extracts tested were between $10000 \mathrm{mg} / \mathrm{ml}$ to $100 \mathrm{mg} / \mathrm{ml}$.

\subsubsection{Broth Dilution Method}

Broth macro dilution is one of the most basic antimicrobial susceptibility testing methods. The procedure involves preparing dilutions of the antimicrobial agent in a liquid growth medium dispensed in tubes containing a minimum volume of $2 \mathrm{ml}$. Each tube is inoculated with a microbial inoculum prepared in the same medium after dilution of standardized microbial suspension adjusted to $0.5 \mathrm{McF}$ arland scale. The inoculated tubes were incubated at $37^{\circ} \mathrm{C}$ for 24 hours after well-mixing.

According to Balouiri et al. (2016), the growth of the organism is inhibited through the lowest concentration of antimicrobial agent MIC as reported by unassisted eye. The most common estimation of fungicidal activity or bactericidal activity is the minimum lethal concentration (MLC). The MLC is also determined as a minimum fungicidal concentration (MFC) or minimum bactericidal concentration (MBC). The lowest concentration of antimicrobial agent is considered as MBC, which is used for killing $99.9 \%$ of the final inoculum under a standardized set of conditions after 24 hours incubation. The number of surviving cells is determined after incubation of 24 hour as negative microbial growth is yielded through the MBC.

\subsubsection{Well-Diffusion Method}

According to Balouiri et al., (2016), the antimicrobial activity of plants extracts is evaluated through this widely used method. A volume of the microbial inoculum over the entire agar surface is spread to inoculate the agar plate surface, likely to the procedure included in disk-diffusion method. A sterile cork borer or a tip is aseptically punched with a volume of the extract solution and a hole of a 6 to $8 \mathrm{~mm}$ diameter (at $1000 \mathrm{mg} / \mathrm{ml}, 500 \mathrm{mg} / \mathrm{ml}, 250$ $\mathrm{mg} / \mathrm{ml}, 125 \mathrm{mg} / \mathrm{l}$ concentration) was dissolved in DMSO. The agar plates were incubated at $37^{\circ} \mathrm{C}$ for $24-48$ hours. The growth of the tested microbial strain was inhibited through no growth showing zone. The zone showing no growth of the tested microorganism was measured and noted as zone of inhibition. $50 \mu 1$ of DMSO was used as negative control; while, ceftriaxone was used as positive control.

\section{Results}

The selection of plants for this study was dependent on available literature of herbs with antimicrobial properties. The anti-bacterial mechanism has been studied to determine active ingredients that are responsible bacterial cell death. A total of 5 extracts including Achinella fragrantissima, Artemisia judaica, Caralluma quadrangular, Rhyza stricta, and Moringa were prepared. These sample extractions were tested for organisms including; Escherichia coli, Pseudomonas aeruginosa, Staphylococcus aureus, and Candida albicans. The other herbal extracts that were tested and showed either had no or less antimicrobial activity against the tested organisms. Table 1 depicts the literature available for the tested herbs.

Table 2 has depicted overall anti-microbial activity of the herbal shrubs and mentioned the organisms that have been tested in the study. The table has also mentioned the quantity of extraction in $\mathrm{ml}$. Table 3 has clearly indicated the herbs, their concentration, and results in the form of inhibitory zones shown by the organisms that were tested in this study. 
Table 2. Antimicrobial activity of herbal extracts

\begin{tabular}{|c|c|c|c|}
\hline Extract & Organism tested & MIC & $\mathrm{MBC}$ \\
\hline \multirow[t]{4}{*}{ Achinella fragrantissima } & Escherichia coli & $250 \mathrm{mg} / \mathrm{ml}$ & $125 \mathrm{mg} / \mathrm{ml}$ \\
\hline & Pseudomonas aeruginosa & $250 \mathrm{mg} / \mathrm{ml}$ & $125 \mathrm{mg} / \mathrm{ml}$ \\
\hline & Staphylococcus aureus & $1000 \mathrm{mg} / \mathrm{ml}$ & $500 \mathrm{mg} / \mathrm{ml}$ \\
\hline & Candida albicans & $500 \mathrm{mg} / \mathrm{ml}$ & $250 \mathrm{mg} / \mathrm{ml}$ \\
\hline \multirow[t]{4}{*}{ Artemisia judaica } & Escherichia coli & $250 \mathrm{mg} / \mathrm{ml}$ & $125 \mathrm{mg} / \mathrm{ml}$ \\
\hline & Pseudomonas aeruginosa & $500 \mathrm{mg} / \mathrm{ml}$ & $250 \mathrm{mg} / \mathrm{ml}$ \\
\hline & Staphylococcus aureus & $1000 \mathrm{mg} / \mathrm{ml}$ & $500 \mathrm{mg} / \mathrm{ml}$ \\
\hline & Candida albicans & $1000 \mathrm{mg} / \mathrm{ml}$ & $500 \mathrm{mg} / \mathrm{ml}$ \\
\hline \multirow[t]{4}{*}{ Caralluma quadrangula } & Escherichia coli & $500 \mathrm{mg} / \mathrm{ml}$ & $250 \mathrm{mg} / \mathrm{ml}$ \\
\hline & Pseudomonas aeruginosa & $500 \mathrm{mg} / \mathrm{ml}$ & $250 \mathrm{mg} / \mathrm{ml}$ \\
\hline & Staphylococcus aureus & $1000 \mathrm{mg} / \mathrm{ml}$ & $500 \mathrm{mg} / \mathrm{ml}$ \\
\hline & Candida albicans & $1000 \mathrm{mg} / \mathrm{ml}$ & $500 \mathrm{mg} / \mathrm{ml}$ \\
\hline \multirow[t]{4}{*}{ Rhyza stricta } & Escherichia coli & $500 \mathrm{mg} / \mathrm{ml}$ & $500 \mathrm{mg} / \mathrm{ml}$ \\
\hline & Pseudomonas aeruginosa & $500 \mathrm{mg} / \mathrm{ml}$ & $250 \mathrm{mg} / \mathrm{ml}$ \\
\hline & Staphylococcus aureus & $1000 \mathrm{mg} / \mathrm{ml}$ & $500 \mathrm{mg} / \mathrm{ml}$ \\
\hline & Candida albicans & $1000 \mathrm{mg} / \mathrm{ml}$ & $500 \mathrm{mg} / \mathrm{ml}$ \\
\hline \multirow[t]{4}{*}{ Moringa } & Escherichia coli & $1000 \mathrm{mg} / \mathrm{ml}$ & $500 \mathrm{mg} / \mathrm{ml}$ \\
\hline & Pseudomonas aeruginosa & $1000 \mathrm{mg} / \mathrm{ml}$ & $500 \mathrm{mg} / \mathrm{ml}$ \\
\hline & Staphylococcus aureus & $1000 \mathrm{mg} / \mathrm{ml}$ & $500 \mathrm{mg} / \mathrm{ml}$ \\
\hline & Candida albicans & $1000 \mathrm{mg} / \mathrm{ml}$ & $500 \mathrm{mg} / \mathrm{ml}$ \\
\hline
\end{tabular}

Table 3. Zones of inhibition obtained from the tested herbal extracts by agar well diffusion method

\begin{tabular}{|c|c|c|c|c|c|}
\hline \multirow[b]{2}{*}{ Herb } & \multirow{2}{*}{$\begin{array}{l}\text { Concentration of } \\
\text { the extract }\end{array}$} & \multicolumn{4}{|c|}{ Microorganisms tested } \\
\hline & & $\begin{array}{l}\text { Escherichia } \\
\text { coli }\end{array}$ & $\begin{array}{l}\text { Pseudomonas } \\
\text { aeruginosa }\end{array}$ & $\begin{array}{l}\text { Staphylococcus } \\
\text { aureus }\end{array}$ & $\begin{array}{l}\text { Candida } \\
\text { albicans }\end{array}$ \\
\hline \multirow{4}{*}{ Achinella fragrantissima } & $1000 \mathrm{mg} / \mathrm{ml}$ & $16.33+/-0.81$ & $9.5+/-0.54$ & $28.33+/-0.81$ & $26.83+/-0.72$ \\
\hline & $500 \mathrm{mg} / \mathrm{ml}$ & $15.33+/-0.51$ & $9+/-0$ & $26.5+/-0.54$ & $24.83+/-0.40$ \\
\hline & $250 \mathrm{mg} / \mathrm{ml}$ & $4.83+/-0.40$ & $7.5+/-0.54$ & $23+/-0.63$ & $20.5+/-0.54$ \\
\hline & $125 \mathrm{mg} / \mathrm{ml}$ & $\mathrm{R}$ & $\mathrm{R}$ & $21.5+/-0.83$ & $18.5+/-0.54$ \\
\hline \multirow{4}{*}{ Artemisia judaica } & $1000 \mathrm{mg} / \mathrm{ml}$ & $16.33+/-0.51$ & $26.16+/-0.40$ & $36+/-0.63$ & $33.16+/-0.75$ \\
\hline & $500 \mathrm{mg} / \mathrm{ml}$ & $14.16+/-0.40$ & $25.16+/-0.75$ & $34.33+/-0.81$ & $32.16+/-0.40$ \\
\hline & $250 \mathrm{mg} / \mathrm{ml}$ & $10.83+/-0.40$ & $23.83+/-0.40$ & $32.16+/-0.75$ & $29.5+/-0.54$ \\
\hline & $125 \mathrm{mg} / \mathrm{ml}$ & $9+/-0$ & $21.5+/-0.54$ & $32.66+/-0.51$ & $27.66+/-0.51$ \\
\hline \multirow{4}{*}{ Caralluma quadrangula } & $1000 \mathrm{mg} / \mathrm{ml}$ & $22.16+/-0.40$ & $23.33+/-0.51$ & $32.83+/-0.40$ & $33.83+/-0.40$ \\
\hline & $500 \mathrm{mg} / \mathrm{ml}$ & $20.16+/-0.40$ & $21.16+/-0.40$ & $30+/-0$ & $28.33+/-0.51$ \\
\hline & $250 \mathrm{mg} / \mathrm{ml}$ & $16.66+/-0.51$ & $18.5+/-0.83$ & $27.16+/-0.40$ & $24.16+/-0.40$ \\
\hline & $125 \mathrm{mg} / \mathrm{ml}$ & $13.16+/-0.40$ & $15.33+/-1.1$ & $24.33+/-0.51$ & $19.83+/-0.40$ \\
\hline \multirow{4}{*}{ Rhyza stricta } & $1000 \mathrm{mg} / \mathrm{ml}$ & $14.66+/-0.51$ & $20.5+/-0.54$ & $27.5+/-0.54$ & $31.83+/-0.75$ \\
\hline & $500 \mathrm{mg} / \mathrm{ml}$ & $12.16+/-0.40$ & $18.83+/-0.40$ & $22.66+/-0.51$ & $29.16+/-0.40$ \\
\hline & $250 \mathrm{mg} / \mathrm{ml}$ & $11.16+/-0.40$ & $17.16+/-0.40$ & $19.83+/-0.40$ & $25.83+/-0.40$ \\
\hline & $125 \mathrm{mg} / \mathrm{ml}$ & $8+/-0$ & $8+/-0$ & $15.83+/-0.40$ & $23+/-0.63$ \\
\hline
\end{tabular}




\begin{tabular}{llllcc}
\hline & $1000 \mathrm{mg} / \mathrm{ml}$ & $19.83+/-0.40$ & $23.16+/-0.40$ & $35.33+/-0.51$ & $33.66+/-0.51$ \\
Moringa & $500 \mathrm{mg} / \mathrm{ml}$ & $17.16+/-0.40$ & $21.33+/-0.51$ & $31.33+/-0.51$ & $27.83+/-0.75$ \\
& $250 \mathrm{mg} / \mathrm{ml}$ & $14.83+/-0.16$ & $18.66+/-0.51$ & $28.83+/-0.40$ & $23.83+/-040$ \\
& $125 \mathrm{mg} / \mathrm{ml}$ & $10.5+/-0.54$ & $16.16+/-0.40$ & $24.5+/-0.54$ & $20.5+/-0.21$ \\
\hline
\end{tabular}

\section{Discussion}

The antimicrobial activities of these extracts have been determined through MIC and disk diffusion methods. A study conducted by Su, et al. (2015) revealed that ethyl ether extraction from Polygonum cuspidatum tends to provide a promising and capable agent for therapeutic applications against nosocomial pathogens. The drug resistant gene transfer occurs due to the spread of drug resistant bacteria among different hosts. A study clearly stated that Staphylococcus aureus, Acinetobacter baumannii, and Pseudomonas aeruginosa are the most common drug resistance and nosocomial infection strains. The infection rate of these organisms is as high as $50 \%$ (Edelsberg et al., 2014).

A study conducted by Hayat et al. (2009) stated Artemisia judaica as diverse and important genus of family Asteracea. It tends to display increased diversity within the temperate areas of northern and southern hemisphere. A study presented results that supported future research on Artemisia judaica including its synergistic and antimicrobial properties. These herbs are extensively applied in the field of medicine, food industry, and agriculture (Janackovic et al., 2015).

Muhaidat, et al. (2015) represented the antibacterial activities and phytochemical composition of important oils, extracted from two jordanian cleome species Cleome species, C. droserifolia and C. trinervia. The report has duly indicated that a number of defense substances are developed through Cleome species while pathogenic microbes are defended through these Cleome species. Thereby, it is recommended that the development of tools against both nosocomial and drug-resistant microbial pathogens is clearly worthy from the discovery of Cleome specie.

Khan, et al. (2016) have examined the organic, non-alkaloid and crude extracts impact on the methicillin-resistant Staphylococcus aureus (MRSA) pathogens as extracted from Rhazya stricta leaves. The antimicrobial activities have been proven through the leaves of medicinal plant R. stricta alongside MRSA clinical isolates. This extraction was entirely based on the $1 \%$ agarose well-diffusion method and TEM. Thereby, it is recommended that MRSA infections might be potentially treated through R. stricta leaves as new antimicrobial compounds.

Abdel-Rahman, et al. (2015) has explored the efficacy of existing medicinal claims with respect to Egyptian folk medicine. An anti-inflammatory activity is exhibited through A. fragrantissima in a carrageenan-induced paw edema of a rat model. The study has shown the efficacy of writhing tests and hot plate tests for exhibiting the analgesic activity of extracts. The study has revealed protective effects of the extracts alongside rat gastric ulcer and ulcerative colitis. In addition, peripheral analgesic and central activities are possessed through A. fragrantissima to ward off gastric and colonic tissues.

In the context of anticancer drug candidate, Jung (2014) has focused on entirely on the potential of water-soluble MOL extracts. Compounds with the highest anticancer activities often possess bulky hydrophobic clusters throughout their chemical structures, which render water insoluble in the field of development process and anticancer drug discovery (Sidduraju \& Becker, 2003). It is identified that severe therapeutic challenges and formulation issues are led by low water solubility. Due to the precipitation of the drug, serious complications are resulted through inappropriate soluble drug administration, which include respiratory system failure and embolism. New water-soluble MOL extracts were focused and examined as an anticancer drug candidate under the study. The increase in resistance among the strains leads to outbreak, if severe nosocomial infections occur. Therefore, the present study has targeted common drug-resistant strains of nosocomial infections for exploring their antimicrobial activity.

In the developing countries, the control of infectious diseases in communities and hospitals is acquired by multi-drug resistant gram-positive and gram-negative bacteria. There is an increase in the implication of different nosocomial infection, which include; urinary tract infections, bacteremia, and nosocomial pneumonia (Radj et al., 2013). Cross-resistance among these bacteria makes the treatment of certain infections difficult along with a large group of activities. Therefore, the exploration of new sources of natural compounds has become easy with anti-bacterial activity against them.

The basis of natural products and traditional medicine system has provided excellent leads for the development of new drug. The anti-microbial activity tends to provide main basis for the therapy of different fungal and bacterial 
infections. The discovery of anti-microbial agents eventually leads to eradication of the infectious diseases. The overuse of these drugs results in the emergence and dissemination of multi-drug resistant strains belonging to different groups of micro-organisms (Harbottle et al., 2006). The results of the current study showed that the tested herbal extracts increased zone of inhibition in the gram-positive organisms like Staphylococcus aureus and Candida albicans (Table 3). This could be in favour of the study conducted by Walsh, et al. (2003), which stated that the impact of antimicrobial activity is associated with the inhibition of various cellular processes. These processes are followed by increase in the permeability of plasma membrane, which might result in the leakage of ions from the cells.

Similar to the present study, Khan, et al. (2009) showed that majority of MIC (Minimum Inhibitory Concentration) values of the extracts were decreased as compared to MFC (Minimum Fungicidal Concentration) values. These results clearly stated that the extracts were responsible for inhibiting the growth of test micro-organisms, when the bacteria and fungi are present at higher concentrations. It is believed that plants are an alternate to battle the spread of multidrug resistant micro-organisms after the emergence of antibiotic resistant pathogens in hospitals as well as homes. These herbal extracts may be applicable and work, efficiently where the modern antibiotic therapy fails. Moreover, appropriate activity of the crude plant extracts has been observed against the multidrug resistant strains.

\section{Conclusion}

The infection caused by nosocomial pathogens results in mild to severe life-threatening illnesses. The study has assessed antimicrobial activities of five plant extracts against the multidrug resistant (MDR) strains. The failure of essential microbial treatment has failed as a result of emergence and spread of drug resistant pathogens. The results have demonstrated promising antimicrobial activities against the most predominant nosocomial pathogens. The use of these plants for treating various diseases has been supported by the gathered results. The plant extracts can also be used for obtaining new and effective herbal medicines for treating infections caused by multidrug resistant strains of certain micro-organisms. Moreover, the results have presented significant positive anti-microbial activity of the herbal shrubs against nosocomial pathogens. The active components of the extracts may be identified and tested separately to focus on the active compound with antimicrobial activity, which could be used as a sole antimicrobial compound or as an additive to the currently used antimicrobials.

\section{Declaration}

The authors declare no conflict of interest. The authors alone are responsible for the content and writing of this manuscript.

\section{Acknowledgments}

We acknowledge the generous support of the Deanship of Scientific Research, University of Tabuk, Tabuk, Kingdom of Saudi Arabia.

\section{References}

Abdel-Fattah, M. M. (2005). Surveillance of nosocomial infections at a Saudi Arabian military hospital for a one-year period. GMS German Medical Science, 3. https://doi.org/10.1016/j.ijid.2008.05.980

Abdel-Rahman, R. F., Alqasoumi, S. I., El-Desoky, A. H., Soliman, G. A., Paré, P. W., \& Hegazy, M. E. (2015). Evaluation of the anti-inflammatory, analgesic and anti-ulcerogenic potentials of Achillea fragrantissima (Forssk.). South African Journal of Botany, 98, 122-127. https://doi.org/10.1016/j.sajb.2015.02.009

Balouiri, M., Sadiki, M., \& Ibnsouda, S. K. (2016). Methods for in vitro evaluating antimicrobial activity: A review. Journal of Pharmaceutical Analysis, 6(2), 71-79. https://doi.org/10.1016/j.jpha.2015.11.005

Centres for Disease Control and Prevention (US). (2013). Antibiotic resistance threats in the United States, 2013. Centres for Disease Control and Prevention, US Department of Health and Human Services.

Edelsberg, J., Weycker, D., Barron, R., Li, X., Wu, H., Oster, G., \& Weber, D. J. (2014). Prevalence of antibiotic resistance in US hospitals. Diagnostic microbiology and infectious disease, 78(3), 255-262. https://doi.org/10.1016/j.diagmicrobio.2013.11.011

Harbottle, H., Thakur, S., Zhao, S., \& White, D. G. (2006). Genetics of antimicrobial resistance. Animal biotechnology, 17(2), 111-124. https://doi.org/10.1080/10495390600957092

Hayat, M. Q., Khan, M. A., Ashraf, M., \& Jabeen, S. (2009). Ethnobotany of the genus Artemisia L. (Asteraceae) in Pakistan. Ethnobotany Research and Applications, 7, 147-162. https://doi.org/10.17348/era.7.0.147-162

Janackovic, P., Novakovic, J., Sokovic, M., Vujisic, L., Giweli, A. A., Dajic-Stevanovic, Z., \& Marin, P. D. (2015). Composition and antimicrobial activity of essential oils of Artemisia judaica, A. herba-alba and A. 
arborescens from Libya. Archives of Biological Sciences, 67(2), 455-466. https://doi.org/10.2298/ABS141203010J

Jung, I. L. (2014). Soluble extract from Moringa oleifera leaves with a new anticancer activity. PloS one, 9(4), e95492. https://doi.org/10.1371/journal.pone.0095492

Khan, R., Baeshen, M. N., Saini, K. S., Bora, R. S., \& Al-Hejin, A. M. (2016). Antibacterial Activity of Rhazya stricta Non-alkaloid Extract against Methicillin-Resistant Staphylococcus aureus. Biol Syst Open Access, 5(157), 2.

Khan, R., Islam, B., Akram, M., Shakil, S., Ahmad, A. A., Ali, S. M., \& Khan, A. U. (2009). Antimicrobial activity of five herbal extracts against multi drug resistant (MDR) strains of bacteria and fungus of clinical origin. Molecules, 14(2), 586-597. https://doi.org/10.3390/molecules14020586

Llewellyn, O. A., Hall, M., Miller, A. G., Al-Abbasi, T. M., Al-Wetaid, A. H., Al-Harbi, R. J., \& Al-Farhan, A. (2010). Important Plant Areas in the Arabian Peninsula: 1. Jabal Qaraqir. Edinburgh Journal of Botany, 67(1), 37-56. https://doi.org/10.1017/S0960428609990229

Muhaidat, R., Al-Qudah, M. A., Samir, O., Jacob, J. H., Hussein, E., Al-Tarawneh, I. N., ... Orabi, S. T. A. (2015). Phytochemical investigation and in vitro antibacterial activity of essential oils from Cleome droserifolia (Forssk.) Delile and C. trinervia Fresen. (Cleomaceae). South African Journal of Botany, 99, 21-28. https://doi.org/10.1016/j.sajb.2015.03.184

Pinelo, M., Rubilar, M., Jerez, M., Sineiro, J., \& Nunez, M. J. (2005). Effect of solvent, temperature, and solvent-to-solid ratio on the total phenolic content and antiradical activity of extracts from different components of grape pomace. Journal of Agricultural and Food Chemistry, 53(6), 2111-2117. https://doi.org/10.1021/jf0488110

Radji, M., Agustama, R. A., Elya, B., \& Tjampakasari, C. R. (2013). Antimicrobial activity of green tea extract against isolates of methicillin-resistant Staphylococcus aureus and multi-drug resistant Pseudomonas aeruginosa. Asian Pacific journal of tropical biomedicine, 3(8), 663-667. https://doi.org/10.1016/S2221-1691(13)60133-1

Sabra, S. M., \& Abdel-Fattah, M. M. (2012). Epidemiological and microbiological profile of nosocomial infection in Taif hospitals, KSA (2010-2011). World Journal of Medical Sciences, 7(1), 1-9.

Scott, R. D. (2009). The direct medical costs of healthcare-associated infections in US hospitals and the benefits of prevention.

Su, P. W., Yang, C. H., Yang, J. F., Su, P. Y., \& Chuang, L. Y. (2015). Antibacterial Activities and Antibacterial Mechanism of Polygonum cuspidatum Extracts against Nosocomial Drug-Resistant Pathogens. Molecules, 20(6), 11119-11130. https://doi.org/10.3390/molecules200611119

Walsh, S. E., Maillard, J. Y., Russell, A. D., Catrenich, C. E., Charbonneau, D. L., \& Bartolo, R. G. (2003). Activity and mechanisms of action of selected biocidal agents on Gram - positive and - negative bacteria. Journal of Applied Microbiology, 94(2), 240-247. https://doi.org/10.1046/j.1365-2672.2003.01825.x

\section{Copyrights}

Copyright for this article is retained by the author(s), with first publication rights granted to the journal.

This is an open-access article distributed under the terms and conditions of the Creative Commons Attribution license (http://creativecommons.org/licenses/by/4.0/). 